\title{
Students' perception on Islamic education toward e-learning classes during covid-19 pandemic
}

\author{
Dewi Suriyani Djamdjuri ${ }^{1}$, Maeleni ${ }^{2}$ \\ Universitas Ibn Khaldun Bogor, Indonesia, ${ }^{1,2}$ \\ dewi.suriyani@uika-bogor.ac.id ${ }^{1}$; maeleni1212@gmail.com² \\ DOI: 10.18326/attarbiyah.v6i1.15-
}

Submitted:

8 February 2021
Accepted:

31 July 2021
Published:

4 August 2021

\begin{abstract}
The aim of this research is to find out the students' perception of Islamic education course conducted online learning during a pandemic outbreak. This impact affects the learning process. The researchers used a qualitative research approach with a survey method and the data collection were gained through a questionnaire and interview which were conducted online. The participants in this study were 115 students from the even semester and of English Education Program in English for Islamic studies course from one of universities in Bogor, Indonesia, who had been involved in online learning during the Covid-19 pandemic. The results show that a hundred percent of the students of that program involved in online learning in 2020/2021 academic year. Moreover, the online media that students are most interested in when learning online are WhatsApp (40.3\%), Google Classroom (35.7\%), Telegram (12.4\%) and Zoom (4.4\%). In addition, according to the students' perception if online learning was extended, some students were very happy, a number of students were unhappy, and a few students were less happy. Despite the fact that most students prefer to study in person (offline) at home, online learning has positive impact on students.
\end{abstract}

Keywords: islamic education 1, e-learning 2, Covid-19 Pandemic 3 


\section{INTRODUCTION}

In December 2019, a pneumonia outbreak was initially reported in Wuhan, the capital of Hubei province in central China. The outbreak has been related to a novel coronavirus (COVID-19), with the initial four cases linked to the Huanan (Southern China) Seafood Wholesale Market, according to experts (Huang et al., 2020). To prevent the spread of COVID-19, UNESCO (2020) stated that over 1.5 billion students around the world were unable to attend school or university as a result of the virus (Huang et al., 2020). National quarantine restrictions were in place until April 20th, 2020.

This is also in line with the Circular Letter of the Indonesian Ministry of Education and Culture, Number 4 of 2020, concerning the Implementation of Education in the Emergency Period of the Covid-19 Pandemic which was later strengthened by Circular Letter Number 15 of 2020 concerning Guidelines for the Implementation of Learning from Home During the Emergency Period of the Spread of Covid-19 (Eka et al., 2020). Many lockdown-style control measures were implemented at the time, including the ban on using public spaces, the encouragement of strict selfisolation and social distancing, the reduction of social life and physical activities to the bare minimum, and the limitation of non-family gatherings to two people (Zawadka et al., 2021). In addition, non-essential travel was prohibited, people were compelled to wear face covers in public settings and maintain a social distance of at least $1,5 \mathrm{~m}$, and youngsters were not allowed to leave the house alone. The declaration of an epidemic emergency in March-April 2020 had a significant impact on the psychological well-being of university students, increasing depression, anxiety, and stress levels (Zawadka et al., 2021).

From March 2020 until now, June 2021, the operation of higher education institutions was restricted. Rectors of numerous universities enacted an order suspending the learning process until the deployment of ICT for the remote teaching process was completed, because all universities were required to undertake entirely remote learning (Zawadka et al., 2021). While countries' COVID-19 infection rates vary, more than 186 countries are currently affected by school closures due to the pandemic. As a result of COVID-19, education has changed dramatically, with a noticeable increase in e-learning, in which teaching is done remotely, virtually, and on digital platforms (Oraif \& Elyas, 
2021). Many colleges decided to conduct online surveys throughout and after the semester to study the perception of remote learning due to unexpected and rapid changes in the teaching and learning process. In terms of building skills and social competences, remote learning during the epidemic was found to be less effective than face-to-face learning (Zawadka et al., 2021).

\section{Remote Learning}

Regarding the implementation of online classes, (Carrillo \& Flores, 2020; Huang et al., 2020) explained that the use of technology in supporting remote learning depends on three pedagogical factors. The pedagogical approach which is the first factor includes student-centred learning, the teacher's role as a facilitator, and knowledge integration. The second factor is learning design which includes learning flexibility, learning according to the individual needs of each student, according to context, social, learning process, and the use of appropriate tools and technology. The third factor is facilitation which includes clear expectations, appropriate questions, understanding and sensitivity to cultural issues, providing timely feedback; constructive; and detail, as well as high attitude and commitment from students (Carrillo \& Flores, 2020; Huang et al., 2020).

Since knowledge is no longer passed down from authority but is instead built in an open, evolving, and dialogic context, allowing communal intelligence to grow (Fandiño \& Velandia, 2020), in today's English language education, technology continues to play an important role in promoting language development (Hussein \& Barzani, 2021). With its accessibility, breadth, expansive digital environments, and capacity to engage with classmates/instructors from different nations, the digital world has the potential to change the classroom, particularly in education. As a result, open education refers to digital education or remote learning (Oraif \& Elyas, 2021). This digital openness could make education more accessible by allowing it to be adapted to individual needs. Because everyone absorbs content differently, information should be acquired in a variety of ways, whether through video, audio, text, or another medium (Oraif \& Elyas, 2021). Many studies have highlighted the benefits of technology in language teaching and learning; its role is not only to engage learners in the learning process, but also to promote learner motivation and learner-centered instruction (Gao \& Zhang, 2020).

E-learning is the art and science of integrating a variety of relevant learning 
materials and activities into which students can collaborate and brainstorm, and it has been around since 2002 under several names (Chaeruman et al., 2018). It is a type of educational technology that helps students to study in a more individualized, active, and collaborative manner. It focuses on creating and maintaining students' networks in their particular contexts through the use of media and technology resources, as well as a continuous and dialogic discussion. Technology was used sparingly in present curricula, but it was dominated by Technology Literacy, which was prominently incorporated in the components of Assessments, Learning Media, and/or Learning Methods (Purnawati \& Iskandar, 2019). Although mobile learning appears to be more beneficial to students than teachers, students will always need guidance and advice from teachers. However, due to the influence of social and contextual factors, teaching with technology can be a complicated and difficult task for some teachers (Gao \& Zhang, 2020).

Students and teachers have faced significant issues as a result of the sudden transition from traditional to online classes. As a consequence, they've brought up a number of challenges, including difficulties with various online teaching platforms, a lack of prior expertise with these platforms, bad internet access, and so on. As well, according to (Eka et al., 2020) the result of their research shows that the challenges are students' economic background affecting their readiness in preparing gadgets and quota to get involved in online learning, internet connection, time, supplementary materials, and heterogeneous students' capability. In addition, from the teachers' perspectives, there are three main challenges in online learning during a pandemic as stated by (Huang et al., 2020). First, teachers have very limited time in preparing and/or adapting offline to online learning materials. Second, the lack or limited opportunities for teachers and students to interact directly and freely during online learning which results in disruption of the learning process. Third, the use of an effective pedagogical approach requires more effort in motivating and activating students in online learning.

The Corona Virus Disease (Covid-19) outbreak that hit more than 200 countries in the world, has presented its own challenges for educational institutions, especially higher education. Anticipating the transmission of the virus, the government has issued various policies, such as isolation, social and physical distancing to large-scale social restrictions (PSBB). This condition requires citizens to stay at home, work, worship and 
study at home. This condition requires educational institutions to innovate in the learning process. One form of this innovation is by learning online or online (in a network).

Online learning or what are commonly called online are a form of internet use that can increase the role of students in the learning process (Saifuddin, 2018). The term online is an acronym for "online". So online lectures are either online learning methods or done via the internet network. Some of the requirements for implementing online lectures include: (a) the organizers of online lecture activities, (b) the positive mindset of lecturers and students in the main function of the internet, (c) the design of a learning process system that can be studied by all students, (d) the existence of an evaluation process of a series of student learning processes, and ( e) feedback mechanism from the organizers (Mustofa, 2019).

Modern learning systems based on information technology provide a wide range of quality that is very suitable for the millennial community that can be accessed at various places and times. This system can be accessed by various levels of society from middle to medium level. The industrial revolution 4.0 makes it easier for people to connect online, such as social media and can access information quickly. The study's findings revealed that students were enthusiastic about utilizing WhatsApp apps to improve their learning. The current study also proposes that learners, instructors, and institutions should be encouraged to use WhatsApp in the development of other language learning processes. The incorporation of WhatsApp allows students to learn autonomously while on the go, thanks to the widespread use of cellular devices (Khan et al., 2021). Moreover, according to Anhusadar's research, WhatsApp is easy to use, the network supports it, it is not as complicated as other apps, it saves data packages, and it is not too tough if the network is not supported (Anhusadar, 2020). Google Classroom allows for more engagement in the learning process, as well as access to and communication with peers (Maskar, 2019).

Mustofa, Mokhamad Iklil et al., (2019) argues that one of the steps to utilize network technology and information technology for the development of learning systems in tertiary institutions is the inter-tertiary education system (online). One of the initiators of this system is the Ministry of Education and Culture of the Republic of Indonesia. The Ministry of Education and Culture through the Directorate General of Higher Education 
created a website pditt.belajar.kemdikbud.go.id which is expected to be an effective means for students to study science without boundaries. The learning process in this way is considered very good, because learning resources can be used for free by thousands of people in need. So, students from universities in remote areas can access courses at leading universities in Indonesia. This learning process will attract students, because the delivery of data prepared in the media is fun, and easy to digest, so it makes students want to know more. Content that is complete, clear, fosters interest in learning, will be increasingly popular until the growth of a smart, knowledge-rich society, even to the point of being able to develop their knowledge through experiments, research, studies which will ultimately be empowered by developing competencies.

\section{Islamic Education}

Based on Muhaimin, Suti'ah and Prabowo (2015) suggests that there are some important things and it should be known about the role as an educator, students and parents in learning in the middle of this outbreak because the learning process is conducted online, it can be known some perspective about the meaning of Islamic education, as follow:

First; Learning based on Islam and an Islamic education system, namely education that is understood and developed and compiled from fundamental teachings and values that must be contained in its basic sources, namely the al-Qur'an and hadith. Second; Islamic religious education, which is an effort to teach Islamic teachings and values related to Islamic teachings, so that it becomes a person's outlook and attitude in life and of course is attached to a person. Third; Education in Islam, or the process and practice of providing education that has taken place and developed since the history of Muslims. In the sense that this process develops in accordance with the existing people.

According to (Darwis, 2019), English for Islamic Studies (EFIS) Course is a subject learned by students about matters in Islam. Such as the importance of Islamic studies, in EFIS learning, there are several good topics in it, namely: An approach to the study of Religion, Dawn of Islam 1 to 3, The Day of Peace, Praying During Travel, Fasting in Islam, Equality in Islam, Culture in Islam, and Visiting in Islam, all of these topics are in EFIS learning, in the other hand English for Islamic Studies Course is important for students because it useful to them. 
Ahmad Tafsir (as cited in Hamzah, Arief Rifkiawan., 2017) stated that the meaning of Islamic education is "Guidance given by a person to someone so that he can develop optimally in accordance with Islamic teachings." When summarized, Islamic education is "Guidance for someone so that he becomes as Muslim as possible." Ahmad Tafsir also defines Islamic education as the word guidance, not by printing and shaping. He realized that in human relationships, all he could do was guide, try to tell, and guide humans.

Islamic education is currently faced with various developments that make it necessary to make changes and improvements so that it is able to make adjustments to these changes. The development of science and technology (science and technology) is a challenge for Islamic education, especially in facing the era of globalization which has been able to systematize distances and times between various countries in the exchange of information and knowledge, especially in the field of Islamic education (Basyar, 2018).

Previous Studies

English for Islamic Studies courses is one of the lessons offered at Bogor Ibn Khaldun University, this shows that this campus considers this learning important and does not consider enough just because the Muslim students of their identity, because of they are Muslims that is why this learning was made on campus. Therefore, English students also need to study the Islamic religious sciences and other reference about Islam out of the classroom. In the study conducted by Muh Ihromi under tittle "The effect of Islamic religious education learning on students ihsan behavior", there are several impacts on students who participated in this course. The data shows that $77 \%$ students consider good behavior.

The other researcher Faridi on his research "Student's Perception on Islam and Muhammadiyah Course", uncovered that this course needs to be taught to students because after students graduate, they would have enough Islamic provisions, as well as having knowledge and understanding to Islam purely, then being able to practice Islamic values in a real life. Based on previous studies, that Islamic Studies Courses have several impacts on the daily lives of students who have participated in this learning. Moreover, the study of Zurqoni also conducted about "Assessment for Islamic Education Learning and Its Impact to Student's religiousness of Islamic University", that state Islamic Education 
Learning in Islamic Universities has an important influence on the religious level. It contributing $54.6 \%$ to improve religiousness in students and also have other factors that influence students' religiousness that need to be further examined. The form of involvement of this research is to improve the learning process of Islamic Education in students at Islamic Universities. The Process of Improving Islamic Learning with substantial material is carried out to improve student sustainability.

Based on (Jamaluddin, Ratnasih, Gunawan, \& Paujiah, 2020) argues that online learning is a transformation process of conventional education in digital form, so it has its own challenges and opportunities. With this online learning system, it can simplify the learning and guidance process when there is an outbreak. This system is a solution for current conditions, so $50 \%$ stated that this system can facilitate the learning and guidance process. But the other half stated that this online learning system could not facilitate the learning process (Munjiat, 2020). The essence of education is a process of transforming values, knowledge and skills. Islamic education in this context explains two matters related to the learning process, as follows: First, In teaching students, we should make them behave as Islamic values, and. Second, In educating students, students must study the teaching material of Islam, as the values of a person's life. Moreover, students may get fatigued, drowsy, and bored as a result of teachers' teaching methods, which solely give material via lecture or exposure. As a result, student motivation in Islamic Education lectures is lowered, and students tend to neglect these sessions. As a result, in the learning process, more innovative strategies, methods, and media are required (Ahsin \& Rahmawati, 2020).

Islamic education is closely related to religious studies such as Islamic education, moral theology, Al-Qur'an-Hadith, tarikh and fiqh learning. in the learning of fiqh in class, the method used is usually the lecture method, the question-and-answer method, the problem-solving method, the demonstration method, methods of giving assignments and others (Hanafi, 2012). Due to conditions that make it impossible to meet face to face so that learning of fiqh which was previously in class becomes an online learning method using virtual technology, utilizing technology such as zoom, teams, WAG etc in their houses. 
Based on the previous literature studies that have been discussed above, the researchers then conducted a research to find out the students' perception of Islamic education course conducted online learning during a pandemic outbreak since it affects the learning process.

\section{METHOD}

In this study, the researchers used qualitative research approach with survey method (Creswell, 2007). The study was selected to the obtain data about the students' perceptions in the English for Islamic Studies course which were carried out through online lectures. The survey via google form was conducted from 28 January 2021 to 29 January 2021, the data were obtained through a questionnaire regarding the implementation, barriers, use of online media/platforms, responses if online learning was extended, comparison of interest in online learning and face-to-face learning in an online English for Islamic Studies Courses. The survey population was all active students of the English language education study program in the English for Islamic studies course consisting of students in semester III, V, and VII. However, in the field, only 115 students filled out the questionnaire. Research respondents were the students of English Education Program in the English for Islamic studies course at Ibn Khaldun University, Bogor, who had been involved in online learning during the Covid-19 pandemic.

\section{RESULT AND DISCUSSION}

Based on a survey via a google form that was conducted from 28 January 2021 to 29 January 2021, some data were obtained regarding implementation, barriers, use of online media/platforms, responses if online learning was extended, comparison of interest in online learning and face-to-face learning in an online English for Islamic Studies Courses. The survey population was all active students of the English language education study program in the English for Islamic studies course consisting of the students in semester III, $\mathrm{V}$, and VII. However, in the field, only 115 students filled out the questionnaire consisting of $70 \%$ women and $30 \%$ men. The distribution of respondents consisted of $38.5 \%$ from semester III, 35.3\% from semester V, 26.2\% from semester VII. Based on questionnaire data, information was obtained that $100 \%$ of students carried out the online learning 
process in the even semester 2020/2021. This condition is due to the current stages that the digital world has the potential to change the classroom, particularly in education. As a result, open education refers to digital education or remote learning become a must (Oraif \& Elyas, 2021).

In the next questionnaire item, it is known that the online media used in Islamic education learning or English for Islamic Studies courses through online learning are various. Respondents can choose more than 1 online media to use. WhatsApp is in the first rank, which is $94.4 \%$, then the second largest is Google Classroom, which is $90.9 \%$, then Zoom use is $85.1 \%$, then Telegram is $75.8 \%$, YouTube is $54.5 \%$ and the rest E-mail with $1.4 \%$. For more detail, could be noticed from the following table 1.

Table 1. The use of Online Media in Learning

\begin{tabular}{cll}
\hline No. & \multicolumn{1}{c}{ Online Media } & User \\
\hline 1 & WhatsApp & $94.4 \%$ \\
2 & Google Classroom & $90.9 \%$ \\
3 & Zoom & $85.1 \%$ \\
4 & Telegram & $75.8 \%$ \\
5 & YouTube & $54.5 \%$ \\
6 & Email & $1.4 \%$ \\
\hline
\end{tabular}

Table 1 shows that the most popular online media when studying in the English Education Study Program in the English for Islamic studies course in the odd semester of 2020/2021, namely WhatsApp and Google Classroom. The high interest in WhatsApp and Google Classroom for online learning is of course reasonable. Using WhatsApp as an online medium is considered easy and simple to use. This is in accordance with the research results by Anhusadar that WhatsApp is easier to use, the network supports, it is not complicated compared to other applications, it saves data packages and is not too difficult if the network is not supported (Anhusadar, 2020). Online learning using Google Classroom can increase interaction in the learning process, can access and communicate with classmates and teachers easily (Maskar, 2019).

Based on the next questionnaire item, information was obtained about the online media that was most preferred by students in learning activities in the English for Islamic Studies course during online learning. As many as $40.3 \%$ of students like WhatsApp, 35.7\% of students liked Google Classroom, 12.4\% of students liked 
Telegram, 7.2\% of students liked YouTube and the remaining 4.4\% liked Zoom, as the data show from the following table.

Table 2 Students' Preferred Online Media

\begin{tabular}{clc} 
No. & \multicolumn{1}{c}{ Online Media } & Students' Preferenc \\
\hline 1 & WhatsApp & $40.3 \%$ \\
2 & Google Classroom & $35.7 \%$ \\
3 & Telegram & $12.4 \%$ \\
4 & YouTube & $7.2 \%$ \\
5 & Zoom & $4.4 \%$ \\
\hline
\end{tabular}

Table 2 shows that the most preferred media chosen by the students is WhatsApp as the first, then Google Classroom as the second media. This condition also shows in line with the previous findings mentioned that learners, teachers, and institutions should be encouraged to employ WhatsApp as well other online media in the development of other language learning processes, according to the current study. Because of the ubiquitous use of cellular devices, the incorporation of WhatsApp allows students to learn independently while on the go (Khan et al., 2021).

In the next questionnaire item, information was obtained that $50.7 \%$ of students responded quite happily, $42.5 \%$ of students were unhappy and $6.8 \%$ of students were less happy if online learning was extended. Although the majority of students prefer to study at home face-to-face (offline), students still feel the positive impact of online learning. As many as $40.3 \%$ of students stated that it was easy to learn anywhere and anytime, $22.6 \%$ stated that they were more sensitive to learning technology, $17.7 \%$ of students stated that the learning style could be adjusted by themselves, $9.7 \%$ of students felt time efficiency, $8.1 \%$ of students can study more calmly and focused, and $1.6 \%$ stated that all positive impacts of online learning were felt by students. The psychological aspects also important to be considered during online learning. According to Muhaimin, Suti'ah, and Prabowo (2015), there are certain crucial things to know about the role of an educator, students, and parents in learning during this outbreak because the learning process is conducted online, so the students feeling better and happy.

The statement of $87.3 \%$ of students who stated that they prefer to study in class face-to-face (offline) was strengthened by student statements about the obstacles that were experienced during online learning at home. As many as 30.3\% stated that students 
became wasteful with internet quotas. Then $26.2 \%$ of students stated that the explanation of the material by the lecturers was not optimal. Then $24.2 \%$ of students stated that internet signal was limited, $16.1 \%$ of students stated that learning interactions were limited and $3.2 \%$ of students stated that online learning media was difficult to follow. Some impacts of online learning toward students show that, they've encountered a variety of hurdles, including issues with various online teaching platforms, a lack of prior experience with these platforms, poor internet access, and so on. In addition, according to (Eka et al., 2020), the challenges are students' economic backgrounds affecting their preparation in preparing devices and quotas, among other things.

\section{CONCLUSION}

From all findings the researchers concludes that all students who filled out the questionnaire stated that $100 \%$ had carried out online learning in the even semester of the 2020/2021 academic year. This shows that all lecturers and students follow the policies of the Government in general and the policies of the University in particular which stipulate that during the Covid 19 pandemic, learning is carried out online or online. Minister of Education and Culture Circular Number: 36962/ MPK.A/ HK/ 2020 concerning "Online Learning and Working from Home in the Context of Preventing the Spread of Corona Virus Disease (Covid-19)" has been carried out well by lecturers and students in the Bogor Ibn Khaldun University of English Education Study Program.

The online lecture system has a positive contribution to suppressing disparities in the quality of higher education institutions in Indonesia. Some of the indications include 1) minimizing the limitations of access to quality higher education, because universities in remote areas can access quality higher education in big cities. 2) breaking the limited facilities that have been considered as one of the obstacles to the low quality of higher education. The online lecture system does not require super sophisticated and expensive facilities, it is enough to use a PC, notebook, tablet, or smartphone, which are currently quite affordable by the public. 3) eliminating the limited understanding of certain materials. The online lecture system provides a more comprehensive understanding than conventional systems, because the material is displayed digitally and in an animated form. 4) The online lecture system provides broad access to educational resources, especially those in leading universities. 
Based on the questionnaire distributed to students of the English Education Study Program at the Bogor Ibn Khaldun University, it was concluded that $100 \%$ of the students of the Educational Technology Study Program carried out online learning in the even semester of the 2020/2021 academic year. However, the majority of students, namely $87.3 \%$ prefer offline learning in face-to-face classes compared to online learning. This is mostly due to the limitations of students in providing continuous internet quotas, inadequate understanding of the material and limited interactions.

Even though students prefer offline learning in class, there are online media that students are most interested in learning online. The results of this survey research can be used as the basis for implementing online learning, especially in the English Education Study Program. Lecturers can consider the form of online learning that will be implemented next.

Moreover, If online learning was extended, some of the students were very happy, a number of students were unhappy, and few of the students were less happy, according to the data. Despite the fact that the majority of students prefer to study face-to-face (offline) at home, online learning has a favorable impact on students.

In addition, based on the research findings, the English for Islamic Studies course is useful and also attracts the attention of students, the researcher wants to suggest that all lecturers who teach the Islamic Studies course at Bogor Ibn Khaldun University to continue teaching this course to English students. In addition, the Islamic Studies course is not only for English classes, but also for each department at Bogor Ibn Khaldun University in the field of education. Lecturers must also have several types of interesting issues related to the topic or material. Therefore, students can gain more experience and more knowledges related to Islam, also can prevent a monotonous atmosphere. The results of this study are expected to motivate teaching lecturers in their additional knowledge and skills in teaching Islamic Studies courses in class. English for Islamic Studies is important to the student because it has many benefits and good effect for them. Furthermore, lecturers must have many Islamic studies references and vocabularies related to Islam to teach students in English that are more interesting. 


\section{REFERENCES}

Ahsin, N., \& Rahmawati, C. (2020). Virtual Learning And Students Motivation: Implementation The "Game Ranking 1st" Through Quizizz. ATTARBIYAH: Journal of Islamic Culture and Education, 5(2). 81-90. https://doi.org/10.18326/ attarbiyah.v5i2.81-90

Anhusdar, L. ode (2020). Persepsi Mahasiswa Piaud Terhadap Kuliah Online di Masa Pandemi Covid 19. KINDERGARTEN: Journal of Islamic Early Childhood Education, 3(1). 44-58. https://doi.org/http:// dx.doi.org/10.24014/kjiece. v3i1.9609.

Basyar, S. (2018). PENDIDIKAN ISLAM DI ERA GLOBALISASI: Antara Konsepsi dan Aplikasi. Al-Idarah: Jurnal Kependidikan Islam, VIII (I). DOI:http://dx.doi.org/ 10.24042/alidarah.v8i1.2989

Carrillo, C., \& Flores, M. A. (2020). COVID-19 and teacher education: a literature review of online teaching and learning practices. European Journal of Teacher Education, 43(4). 466-487. https://doi.org/ 10.1080/02619768.2020.1821184

Chaeruman, U. A., Wibawa, B., \& Syahrial, Z. (2018). Creating a Blended Learning Model for Online Learning System in Indonesia. International Journal ofEngineering E Technology, 7(3.36). 156.https://doi.org/10.14419/ijet.v7i3. 36.29098

Darwis, D. (2019). English for islamic studies. Jakarta: Rajawali Press.

Eka, P., Suputra, D., Nitiasih, P. K., Made, I., \& Paramarta, S. (2020). Kelas Daring Bahasa Inggris di Masa Pandemi: Sebuah Tantangan Pembelajaran. Seminar Nasional Riset Inovatif, 7, 110-118. https://eproceeding.undiksha.ac.id/index.php/senari /article/view/2129

Fandiño, F. G. E., \& Velandia, A. J. S. (2020). How an Online Tutor Motivates E-learning English. Heliyon, 6(8). https://doi.org/10.1016/ j.heliyon.2020.e04630

Gao, L. X., \& Zhang, L. J. (2020). Teacher Learning in Difficult Times: Examining Foreign Language Teachers' Cognitions About Online Teaching to Tide Over COVID-19. Frontiers in Psychology, 11(September), 1-14. https://doi.org/10. 3389/fpsyg.2020.549653 
Hamzah, A.R. (2017). Konsep Pendidikan dalam Islam Perspektif Ahmad Tafsir. AtTajdid, 1(1). 73-89 Retrieved fromhttps://ojs.ummetro.ac.id/index.php/ attajdid/article/view/336

Hanafi, I. (2012). Orientasi Fikih dalam Pendidikan Islam. Al-Fikra: Jurnal Ilmiah Keislaman, 11(1), 16-35. https://doi.org/10.24014/af.v11i1.3850.

Huang, R., Tlili, A., Chang, T. W., Zhang, X., Nascimbeni, F., \& Burgos, D. (2020). Disrupted classes, undisrupted learning during COVID-19 outbreak in China: application of open educational practices and resources. Smart Learning Environments, 7(1). https://doi.org/10.1186/s40561-020-00125-8

Hussein, S., \& Barzani, H. (2021). The Role of Technology in ELL Classes in Turkish Republic of Northern Cyprus. International Journal of Language Education, 5(2), 30-39.

Jamaluddin, D., Ratnasih, T., Gunawan, H., \& Paujiah, E., (2020) Pembelajaran Daring Masa Pandemik Covid-19 Pada Calon Guru: Hambatan, Solusi Dan Proyeksi. Karya Tulis Ilmiah, Lembaga Penelitian dan Pengabdian Kepada Masyarakat UIN Sunan Gunung Djati Bandung. Retrieved from https://core.ac.uk/ download/pdf/305072868.pdf

Khan, R. M. I., Radzuan, N. R. M., \& Farooqi, S.-H. (2021). Learners ' Perceptions on WhatsApp Integration as a Learning Tool to Develop EFL Vocabulary for Speaking Skill. IJOLE: Internation Journal of Language Education, 5(2), 1-14. DOI:

Maskar, S. (2019). Persepsi Peserta Didik terhadap Metode Blended Learning dengan Google Classroom. Inovasi Matematika, 1(2), 110-121.https://doi.org/10.35438 /inomatika.v1i2.156.

Muhaimin., S. (2015). Manajemen Pendidikan (Aplikasinya dalam Penyusunan Rencana Pengembangan Sekolah/Madrasah). Jakarta: Prenada Media.

Munjiat, S. M. (2020). Implementation of Islamic Religious . (2020). Education Learning in. Nazhruna: Jurnal Pendidikan Islam, 3(2), 285-295. DOI:

https://doi.org/10.31538/nzh.v3i2.757.Mustofa, M. I. (2019). Formulasi Model Perkuliahan Daring Sebagai Upaya Menekan Disparitas Kualitas Perguruan Tinggi. Walisongo Journal of Information Technology, 1(2),, 151. https://doi.org/10. 21580/wjit.2019.1.2.4067. 
Saifuddin, M. F. (2018). E-Learning dalam Persepsi Mahasiswa. Jurnal VARIDIKA, 29(2), 102-109. https://doi.org/10.23917/varidika.v29i2.5637.

Oraif, I., \& Elyas, T. (2021). The impact of COVID-19 on learning: Investigating EFL learners' engagement in online courses in Saudi Arabia. Education Sciences, 11(3), 1-19. https://doi.org/10.3390/educsci11030099.

Purnawati, \& Iskandar, I. (2019). Designing Ict Competences-Integrated Syllabuses of Grammar Courses for English Language Education Study Program. Ijlecr: International Journal of Language Education and Culture Review, 5(2), 104-115. https://doi.org/10.21009/ijlecr.052.12.

Zawadka, J., Miękisz, A., \& Nowakowska, I. (2021). Remote learning among students with and without reading difficulties during the initial stages of the COVID 19 pandemic. Education and Information Technologies, 0123456789. https://doi.org/10.1007/s10639-021-10559-3 